\title{
Exchange Rate Mechanism II and the risk of currency crisis - empiricism and theory
}

\author{
Mojmír Helísek \\ Department of Economics, \\ University of Finance and Administration, \\ Crech Republic \\ mojmir.helisek@vsfs.cz.
}

Abstract: Currency participation in ERM II is conditional on the introduction of the fixed exchange rate regime. A fixed exchange rate is more at risk from a currency crisis than a flexible exchange rate. These concerns are also expressed in the official strategy for the introduction of euro in the Czech Republic. The goal of this paper is to evaluate the risk of a currency crisis using two methodological approaches. First, from the empirical perspective. In the history of ERM II, no currency has been affected by such currency crisis. Second, from the theoretical perspective. A currency crisis in ERM II can be explained by second-generation models that do not take into account for the fundamental causes of investor distrust and emphasize the importance of devaluation expectations. We have defined five specific risks associated with entry into ERM II which could be the cause of devaluation expectations. We have also explained three reasons why the central bank will try to maintain a fixed exchange rate in ERM II. This will weaken devaluation expectations. These specific risks, leading to devaluation expectations, and these reasons for weakening devaluation expectations, are applied to the second-generation model (we have modified this model according to ERM II conditions). We have concluded that concerns over a currency crisis from participation in ERM II are unfounded.

Keywords: euro, ERM II, currency crisis, euro area enlargement, fixed exchange rate.

JEL Classification: F31, F33, F36

\section{INTRODUCTION}

Most new EU Member States have already replaced their national currency with euro. The remaining countries are still postponing its introduction. Postponing the introduction of euro has many causes. The distrust to euro in the Czech Republic is explained.

One of these causes is the obligation to meet the exchange rate stability criterion (one of the Maastricht convergence criteria). This criterion means fixing the exchange rate of a given currency to euro 
within the exchange rate mechanism which was created together with the emergence of the euro area (ERM II) for at least two years. However, a currency that maintains a fixed exchange rate is threatened by a currency crisis.

The motivation of this paper is the concern over a currency crisis that could occur after Czech koruna joins ERM II. These concerns are quite specifically expressed in the official documents of Czech authorities. The Czech Republic's Euro Area Accession Strategy (2003, p. 3, emphasis by M.H.) calls for the shortest possible participation in ERM II. The reason is as follows: "Given that participation in the ERM II [...] does not in itself eliminate the risk of currency turbulence, it is regarded merely as the gateway into the euro area. [...] staying in the ERM II for longer than the minimum required period of two years does not seem desirable". This position is more detailed in the study of the Czech National Bank ERM II and the Exchange-Rate Convergence Criterion (2003, pp. 4, 6, emphasis by M.H.) "The ERM II [...] is a fixed exchange rate regime. [...] In a world of massive capital flows [participation in ERM II] may be associated with potential costs as the financial markets "test" the willingness of the authorities to maintain the exchange rate within the fluctuation band".

At present, only one currency is involved in ERM II, namely the Danish krone (DKK), which has been in ERM II since 1999, i.e., from the start of ERM II. The central parity to euro is still the same, namely DKK 7.46038/EUR; with the fluctuation band of $\pm 2.25 \%$. The exchange rate was almost stable throughout the period between January 1999 and October 2018 and any fluctuations by no means reached the margins of the fluctuation band (Figure 1). The maximum fluctuations in the exchange rate were:

- in the depreciation direction at the end of 2000 and in the spring of 2014 (roughly $0.1 \%$ around the central parity),

- in the appreciation direction at the end of 2002 and early 2003 (roughly $0.5 \%$ around the central parity).

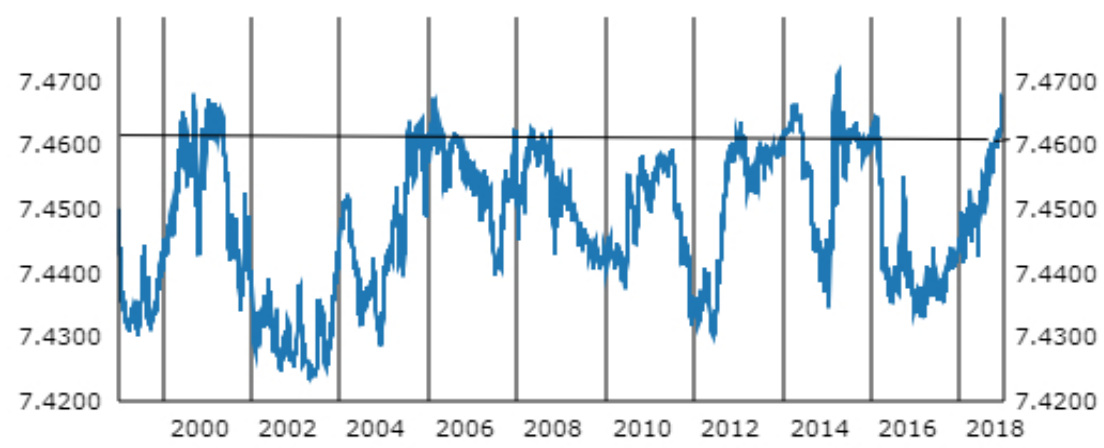

Figure 1. Development of exchange rate DKK/EUR, 1999-2018 (daily rates)

Source: European Central Bank

http://sdw.ecb.europa.eu/quickview.do?SERIES_KEY=120.EXR.D.DKK.EUR.SP00.A

The paper deals exclusively with the period prior to the adoption of euro and, therefore, it examines non-members euro area countries. The article does not investigate the consequences from the introduction of the euro, or a hypothetical "euro crisis" or "euro area crisis".

The paper aims to identify the risk of a currency crisis during the national currency's participation in ERM II. What are the experiences of the countries that have been involved in ERM II and the euro already in place? Are there any special circumstances connected with the fixed exchange rate in ERM II before the introduction of euro? We consider the findings to be universal, applicable not only to Czech 
koruna, but also useful to other national authorities when deciding on participation of their national currencies in ERM II.

The paper is structured as follows. After the literature overview (section 2) we explain our methodological approaches, namely the empirical and the theoretical approach to assessing the currency crisis risk during participation in ERM II (section 3). Section 4 describes currency crises (their definitions, measurement, causes) and briefly summarises three generations of theoretical models of currency crises (including references to historical literature). Section 5 explains why currency crises are linked to a fixed exchange rate and then evaluates which of the currency crises models is best suited to ERM II conditions. It is the model that does not work with the "fundamental causes" of currency crises, but with "selffulfilling devaluation expectations" (one of the second generation models). Section 6 (the main part of the paper) first evaluates empirical knowledge of currency crises in ERM II. And then it defines the specific causes of devaluation expectations in ERM II (as well as the factors that counteract these expectations) and applies these causes to a selected currency crisis model. The result is our modification of this model and assessment of the currency crisis risk in ERM II.

\section{LITERATURE REVIEW}

The criterion of exchange rate stability before entering the euro area is addressed by many authors. However, only some of them draw attention to the risk of a currency crisis during the participation in ERM II.

De Grauwe (2016, p. 155) considers ERM II to be only a temporary regime that allows a rapid adoption of the euro. Otherwise (when entry into the euro area is delayed), participation in ERM II is undesirable. "It may then face similar problems to those the EMS experienced in 1992-1993 with speculative crises and a collapse of the arrangement."

Krawczyk (2004, pp. 7-9) compares the ERM mechanism (part of the European Monetary System, EMS) with ERM II. He sees risks of joining ERM II in three areas: (1) In the original ERM system always parities of two currencies have been set and the two currency pair countries were involved in maintaining this parity (in foreign exchange interventions). ERM II is about keeping the parity against the euro, and the ECB does not (according to Krawczyk) have an obligation to maintain this parity. Therefore, even with a relatively wide fluctuation band, ERM II is equally prone to crises as the original ERM mechanism. (2) The EU membership of new countries was conditioned by free capital mobility. There are a number of circumstances, such as the loss of confidence in the economic policy or higher inflation expectations, which will lead to a rapid outflow of capital, which is incompatible with maintaining a fixed exchange rate in ERM II. (3) To maintain a currency in ERM II requires stability of the banking system. In the new member states this banking system is undercapitalised. This can lead to a combined banking and currency crisis. Krawczyk concludes: "It seems possible to argue that insisting on the ERM II participation [...] means a disregard to the experience of the 1990s currency crises and makes the waiting period inside the ERM II likely to become a self-defeating experiment." (p. 9)

Dyson (ed., 2006) also warns against “speculative attacks” during the ERM II participation: „Critics loath the ERM II as a »soft peg" prone to speculative attacks" (p. 163). These attacks are due to destabilized expectations of investors, caused by shifts in monetary policy, on the one hand, and fluctuations in currency exchange rates on the other. It also explains why the shortest possible period of participation in ERM II is envisaged not only by the Czech Republic, but also by Poland. "The concern in both cases is that financial markets will use participation in the ERM II as an excuse to speculate against their national currencies." (p. 99). 
Michalczyk (2011, p. 128) accurately describes the risk of speculative attacks: “[...] it must be remembered that formal accession to the ERM II, although assumed to result in a higher degree of the exchange rate stability, may cause tensions in the foreign exchange market, being a consequence of speculation and the desire to "test" the authorities by market entities (vide European currency crisis in first half of the nineties)." Similarly also Backé et al. (2004, p. 6):“Acceding countries regard ERM II as an intermediate exchange rate regime, subject to risks of speculative attacks." The same concerns over "Spekulationsbewegungen" during participation in ERM II is also expressed by Brasche (2017, p. 227). Palankai believes that the Hungarian forint can be considered an example of a currency threat in ERM II. This kept the peg to the euro with an oscillation of $\pm 15 \%$ in 2001-2008. Then was introduced a free floating "just due to the speculative threats of the financial crisis" (Palankai, 2015, p. 54).

In Czech literature, warning against a currency crisis can be found in Lacina, Rozmahel et al. (2010, p. 21): "In addition, participation in ERM II for two years poses a risk of speculative attacks on the currency of the candidate countries." Sychra (2009) points out "potential instability" during the period of the currency staying in ERM II; the same by Marková (2011).

None of the above studies, however, contains a definite explanation of the specific causes of a (hypothetical) currency crisis during the ERM II participation.

\section{METHODOLOGY}

We use two approaches to assessing the risk of a currency crisis during the participation of a national currency in ERM II.

First, we evaluate (by analysis and comparison) the existing empirical data related on the participation of national currencies in ERM II. We define the "currency crisis" criteria and then we them compare with actual development indicators:

- exchange rate development,

- indicators of pressure on the exchange rate.

Has there ever been a currency crisis? To answer this, we use statistical data from the European Central Bank's Convergence Reports.

Second, we use the various theoretical models of the currency crisis (modelling application). Which of these models can be applied to ERM II fixed exchange rate conditions? We evaluate the selected model:

- both in its original (general) version for any fixed exchange rate

- and in our (specific) version for a fixed exchange rate in ERM II.

The result is our modified model with specific risks and with specific reasons for weakening of these risks in ERM II.

The conclusions about the currency crisis risk indicate measures how to face these risk - what central bank's measures mitigate the devaluation expectations.

\section{BACKGROUND - CURRENCY CRISES AND THEIR CAUSES}

\subsection{Characteristics of currency crises}

A currency crisis means a significant depreciation of the nominal exchange rate of a given currency. The terms "devaluation crisis", "foreign exchange crisis" or "speculative crisis" are also used as a synonym. Definitions of the terms "currency crisis", "banking crisis", "debt crisis", and "financial crisis" can be found in the key study of the International Monetary Fund (1998). 
The cause for this depreciation is the investors' distrust of this currency and the resulting devaluation of its exchange rate. Investors therefore transfer their assets in that currency to assets in other currencies. There are two groups of such investors. In the case of speculation investors, these deals are referred to as "an attack by eager speculators" who want to maximize their profits. In case of investors who diversify assets in their portfolios, this is an "escape of cautious investors" who want to minimize their losses (Mentel at al., 2017). Central banks typically defend the fixed exchange rate for some time, which leads to a decline in their foreign exchange reserves and an increase in interest rates. They can also introduce an administrative control of capital movements. Investors, however, will finally get the central bank to devalue or (more often) abandon the fixed exchange rate and then depreciate it.

Empirical definition of a currency crisis usually distinguishes a narrower and a wider approach to the crisis (Glick \& Hutchison (2011, pp. 7-8). According to the narrower approach, a currency crisis occurs if the exchange rate of a currency relative to the reference currency (usually USD) exceeds the average annual rate of depreciation of $25 \%$ with the year-on-year depreciation rate of at least $10 \mathrm{pp}$. (this criterion still being used was introduced by Frankel, Rose, 1996, pp. 352-353; other authors use different modifications thereof). According to the wider approach, a currency crisis is identified by the exchange rate pressure index, which includes, in addition to the above exchange rate, a change in foreign exchange reserves and the interest rate, always relative to a certain reference value (Eichengreen et al., 1996, pp. 474-475; further elaborated by Kaminsky et al. 1998). We can consider for the currency crisis also the "reflected" speculative attack (the exchange rate remained stable), which was accompanied by significant changes in these two indicators.

In addition to these two approaches to currency crises, literature also mentions the possibility to define a currency crisis solely on the basis of a "qualitative criterion", such as forced parity change, abandonment of fixed exchange rate or international aid (Bordo et al., 2001). This qualitative criterion (= abandoning the fixed exchange rate) can also be used to describe the currency crisis of the Czech koruna in May 1997 (see Helísek, 2004, pp. 137-146).

Currency crises were relatively frequent in the 1980s and 1990s, affecting an average of 5-10 currencies per year. At the beginning of the 21 st century, their frequency has fallen sharply, but has been rising again since 2007 in the context of the financial crisis. According to Glick and Hutchison (2011, p. 19), in 2008-2009 there were 23 currencies that depreciated by 25\% or more. Bush et al. (2011, p.7) report the frequency of currency crises averaging 5.4 per year between 1973 and 1989; 2.4 per year between 1990 and 2009.

What are the causes of currency crises? Here we provide only a basic explanation (for more detail, see Helísek, 2004, p. 69 et seq.). We do not address conspiracy theories alleging that monetary crises are due to a targeted attack by speculators (G. Soros being a typical example) who start a currency crisis to "punish" unwanted political leaders.

What causes devaluation expectations in investors? These expectations are usually caused by unfavourable economic development in the country, a deterioration of the so-called fundamental economic variables. These variables can also be considered as "currency crisis indicators". These indicators are widely covered in literature. More recent literature dealing with currency crises in developed countries (i.e. also countries whose currencies are in ERM II) includes, for example, Babecký et al. (2012, p. 24), providing the following indicators:

- worsening government balance,

- falling central bank reserves,

- increasing money market rate.

Distrust of investors may also be caused by their distrust of market data in countries where a currency crisis breaks out, or even distrust of institutions in these countries: "Thus, the financial crises in 
Mexico (1995), South East Asia, Russia and Brazil (1997-1998) and Argentina (2001-2002) were [...] the product of lack of transparency, widespread corruption and macroeconomic mismanagement" (OteroIglesias, 2014, p. 62).

However, a currency crisis need not be due to deterioration of the fundamentals. It may be due to mere expectation of their future deterioration, under the influence of an ongoing currency crisis in a different, but similar, economy. This is referred to as pure contagion. A specific case of the pure contagion is the regional view of investors, in which investors project the assessment of one economy of a given region to all countries of that region because of their similarity.

\subsection{Models of currency crises}

Devaluation expectations due to different causes lead to central authorities choosing to abandon the fixed exchange rate. Different combinations of the above-mentioned causes and decisions of authorities on devaluation are studied by currency crisis models. These models are generally divided into three generations (summary reports are given in e.g. Helísek, 2004; Glick \& Hutchinson, 2011; Krugman 2013; Zenker, 2014).

The first generation of currency crisis models are models with the so-called fundamental causes of crises. If these fundamentals deteriorate (often due to inappropriate macroeconomic policies), it leads to a capital flight and a fall in foreign exchange reserves, which forces the country's authorities to abandon the fixed exchange rate. The crises are then regarded as deserved and predictable. The basic version of this model was created by Krugman (1979), and developed by Flood and Garber (1984). These models responded to the break-up of the Bretton Woods system and (among others) to the currency crises in the 1970s and 1980s, in Russia and Brazil (1998-1999) or Argentina (2002).

In the second generation of currency crisis models, the central authority is considering whether or not to accept exchange rate devaluation, whether or not to abandon its commitment to maintain a fixed exchange rate. Therefore, these models are called "escape-clause models". Central authorities compare the costs and benefits of devaluation (see below). In these models, currency crises are unpredictable, the deterioration of fundamentals may not be significant, and self-fulfilling expectations play a significant role here. The basics of these models were described in Obstfeld $(1994,1996)$ and Krugman (1996). The models responded to the crisis of the European Monetary System in 1992-1993 or to the Mexican crisis of 1994-1995.

The third generation of the models focuses on the corporate sector (corporate balance sheet models). The models work with a number of financial indicators of businesses, such as financial vulnerability, moral hazard and over-investment, or the impact of foreign debt of companies increasing as a result of devaluation. The models also explain the causes of the so-called twin crisis, i.e. the currency and banking crises together. The authors of these models include, for example, Krugman (1999) or Corsetti et al. (1999). These models explain the currency crises in Asian countries in 1997-1998.

\section{CURRENCY CRISIS RISK IN ERM II}

\subsection{Concerns over fixing the exchange rate}

Currency crises usually affect currencies maintaining a fixed exchange rate. Why are flexible exchange rate currencies less vulnerable to a currency crisis? Because in this case there is less (or no) defence of the exchange rate by central bank interventions on foreign exchange markets. Therefore, foreign exchange reserves are not depleted, unlike in the fixed exchange rate system, where the temporary defence of the 
exchange rate leads to the loss of part of these reserves. A sufficient volume of foreign exchange reserves (in case of a flexible exchange rate) then alleviates the fears of investors that they could not transfer their receivables from that currency to another currency. Consequently, the investors do not panic. "The combination of depleted reserves and broken promise [to keep a fixed exchange rate - note by M.H.] leads to the country being very vulnerable to the crisis. With a floating system, countries can maintain their reserves and thus prevent financial panic." (Radelet, \& Sachs, 2001, pp. 306-307). A currency crisis is therefore less likely in case of the flexible exchange rate regime.

In all major cases of currency crises such as the 1994-1995 Mexican crisis, the 1997-1998 Asian crisis, the 1998-2000 Russian crisis, the 1999 Brazilian crisis or the 2002 Argentine crisis, the affected economies maintained some of the fixed exchange versions (see Helísek, 2004). More recent research also leads to the same conclusion (Melvin, \& Norrbin, 2017, p. 213): "Fixed exchange rates encouraged international capital flows into the countries [...] Once pressures for devaluation began, countries defended the pegged exchange rate by central bank intervention $[\ldots]$ and the fixed exchange rate is abandoned."

Participation in ERM II is associated with introducing of one of the fixed exchange rate regimes (see Helísek, \& Mentlík, 2018):

- a peg against the euro without a fluctuation band,

- a peg within ERM II with a standard fluctuation band of $\pm 15 \%$,

- or with a narrowed band which must be agreed in advance,

- $\quad$ euro-based currency board.

The concerns over a currency crisis during the participation of the Czech koruna in ERM II therefore seem justified.

\subsection{Model selection in ERM II}

As mentioned in section 4.1 of this paper, investors' distrust leading to the pressure on the exchange rate devaluation may be due to the deterioration of fundamental economic variables. However, a currency crisis ("speculative attack") may also occur in a "fundamentally sound" economy. We believe that the second generation of models that explain monetary crises without a significant deterioration of economic fundamentals is the most accurate to interpret the risk of a currency crisis during the participation in ERM II. The reason why we have chosen this model is the necessary fulfilment of:

- the Maastricht convergence criteria (low inflation, low interest rates, "healthy" public finances)

- and of the complementary criterion, i.e. the low current account deficit.

In these currency crisis models, also referred to as escape clauses models, the authorities maintain a fixed exchange rate regime, but it is not fixed irrevocably. Under certain circumstances, a fixed exchange rate may be revoked using the so-called escape clause, i.e. by cancelling the commitment to maintain a fixed exchange rate. What are those "certain circumstances"? The economy may be (according to Obstfeld) affected by some exogenous shock, which leads, for example, to a rise in the price level. The authorities' efforts (their restrictive policy) for its stability then leads to a growth of unemployment. The worsening of the fundamental economic indicators (such as the above mentioned unemployment) causes that investors to distrust this economy and its currency. That is why they expect devaluation which the authorities expect to boost competitiveness and reduce unemployment. The devaluation pressure exerted by investors (as they get rid of given currency) will thus intensify until the authorities finally carry out the devaluation. However, the fundamental economic variables are not relevant here; what is relevant are the devaluation expectations. Devaluation occurs because it is expected. Obstfeld's approach is therefore characterized as an "an illustrative model in which high unemployment may cause an exchange-rate crisis 
with self-fulfilling features." (Obstfeld, 1996, p. 1037). Random events triggering currency crises are generally referred to as "sunspots" (Ibid., p. 1044).

For the purposes of interpreting this currency crisis model under ERM II conditions, we will use the De Grauwe's approach (2016, pp. 102-105). The fundamental variable that investors monitor and use to evaluate the credibility of a given currency is, in the original example by DeGrauwe, the deficit of the current account balance of payments. Similarly, it could be another fundamental variable, such as the public finance deficit, declining foreign exchange reserves or rising interest rates (see section 4.1). Figure 2 shows this quantity on a horizontal axis, indicated by the symbol $\varepsilon$.

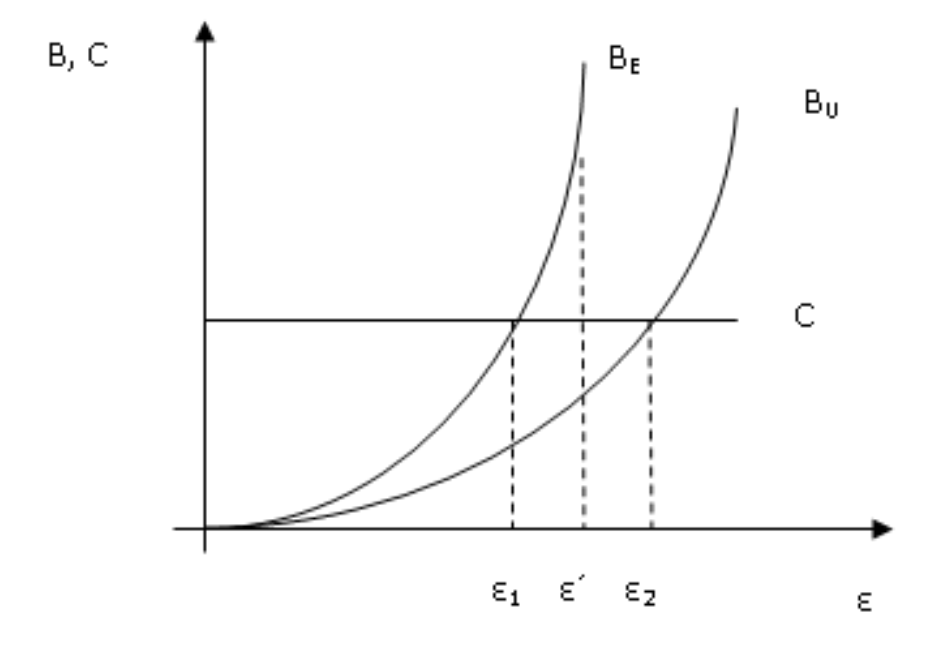

Figure 2. Currency crisis without fundamental causes Source: De Grauwe (2016), p. 105.

Authorities are aware of the unfavourable effect that an increase in this quantity has on investors' decision-making, and are therefore trying to reduce it by their restrictive policy. This, however, leads to an increase in unemployment. If authorities decide to devalue the currency (or leave the fixed exchange rate), they do not have to pursue this restrictive policy and will consequently reduce unemployment. Devaluation is therefore beneficial. This benefit is measured on the vertical axis; is marked as B (benefit). The combination of $\varepsilon$ and $\mathrm{B}$ is expressed by the upward curve $\mathrm{B}$ : the less favourable the economic development, the higher the devaluation benefit. The shape of curve $B$ is explained by the indifference analysis principle. The curve $\mathrm{B}$ has two variants. The lower curve $\mathrm{B}_{\mathrm{U}}$ does not reflect devaluation expectations. The higher curve $\mathrm{B}_{\mathrm{E}}$ reflects devaluation expectations, i.e. there is a "speculative attack" (in these expectations the authorities need to opt for stronger restrictive policy; devaluation would therefore have a higher benefit for them). However, the devaluation is also associated with costs (in the figure, they are marked as C, costs). Let's suppose these costs are fixed. Figure 2 shows this as the horizontal line C. De Grauve explains these costs as a loss of authorities' reputation. Another variant of this model (Sachs et al., 1996, p. 270) specifies the following costs: "Government that commit to a peg and then renege on the promise typically face costs - loss of pride, voter disapproval, maybe even removal from office [...]."

Let us now explain the relation between $\varepsilon, \mathrm{B}$ and $\mathrm{C}$ :

- if the observed fundamental variable is strongly favourable $\left(\varepsilon<\varepsilon_{1}\right)$, there will be no devaluation, since $\mathrm{C}>\mathrm{B}$;

- conversely, if it is significantly unfavourable $\left(\varepsilon>\varepsilon_{2}\right)$, there will be devaluation because B $>C$; 
- if $\varepsilon$ is somewhere "in the middle" around $\varepsilon$ ', then it depends on the expectations of investors ("markets").

In the interval " $\varepsilon_{1}-\varepsilon_{2}$ ":

- there will be no devaluation if investors do not expect it;

- there will be devaluation if investors expect it,

In other words, the depreciation of the exchange rate (= currency crisis) is due to the expectation of this crisis. It is a self-fulfilling expectation. This model of a currency crisis therefore explains that a change in fundamental economic variables is not important in case of their "middle level". The devaluation (or leaving the fixed exchange rate) is determined by investors' expectations. De Grauwe (2016, p. 106, emphasis by M.H.) adds: "Thus, when the shock is intermediate in size, there are two possible equilibria that depend solely on the state of expectations. When agents do not expect a devaluation the authorities have no incentive to devalue, so the exchange rate remains fixed. When, however, speculators expect devaluation, the ensuing speculative attack creates an incentive for the authorities to devalue, and there will be a devaluation. [...] This makes the fixed exchange rate arrangement very fragile."

\section{DISCUSSION - CAN A CURRENCY CRISIS OCCUR IN ERM II?}

\subsection{Empirical data about currency crises in ERM II}

So far, seven currencies have participated (before the introduction of the euro) in ERM II (Table 1. The specific case of Greece, the eighth country, which has moved from ERM to ERM II, is not mentioned here). Table 1 reflects the evolution of the exchange rates over the two-year period as assessed in the ECB Convergence Reports. The last column in the table shows the maximum deviation from the central parity (in \%, daily rates); Slovakia revalued the central parity by $8.5 \%$ on 19 March 2007; therefore the data before and after the revaluation are presented separately.

Table 1

Participation of currencies in ERM II

\begin{tabular}{|l|l|l|l|l|l|}
\hline \multirow{2}{*}{$\begin{array}{c}\text { Country } \\
\text { (currency) }\end{array}$} & In ERM II since & $\begin{array}{c}\text { Euro } \\
\text { since }\end{array}$ & \multicolumn{1}{c|}{ Monitored period } & \multicolumn{2}{c|}{ Maximum deviations (\%) } \\
\cline { 5 - 6 } & & & appreciation & depreciation \\
\hline Slovenia (SIT) & 28 June 2004 & 2007 & 1 May 2004 - 28 April 2006 & 0.1 & -0.2 \\
\hline Cyprus (CYP) & 2 May 2005 & 2008 & 2 May 2005 - 26 April 2007 & 2.1 & 0.0 \\
\hline Malta (MTL) & 2 May 2005 & 2008 & 2 May 2005 - 26 April 2007 & 0.0 & 0.0 \\
\hline Slovakia (SKK) & 28 November 2005 & 2009 & 19 April 2006 - 18 April 2008 & $11.8 ; 8.9$ & $-0.7 ; 0.0$ \\
\hline Estonia (EEK) & 28 June 2004 & 2011 & 24 April 2008 - 23 April 2010 & 0.0 & 0.0 \\
\hline Latvia (LVL) & 2 May 2005 & 2014 & 17 May 2011 - 16 May 2013 & 1.0 & -1.0 \\
\hline Lithuania (LTL) & 28 June 2004 & 2015 & 16 May 2012 - 15 May 2014 & 0.0 & 0.0 \\
\hline
\end{tabular}

Sources: European Central Bank, Convergence Report (various years).

Figure 3 shows fluctuations in the exchange rate over a two-year period. Estonia and Lithuania maintained the currency board regime; Malta maintained the $0 \%$ fluctuation band in both directions. Therefore, we do not provide the figures for these three currencies (horizontal lines at central parity). 
Slovenia

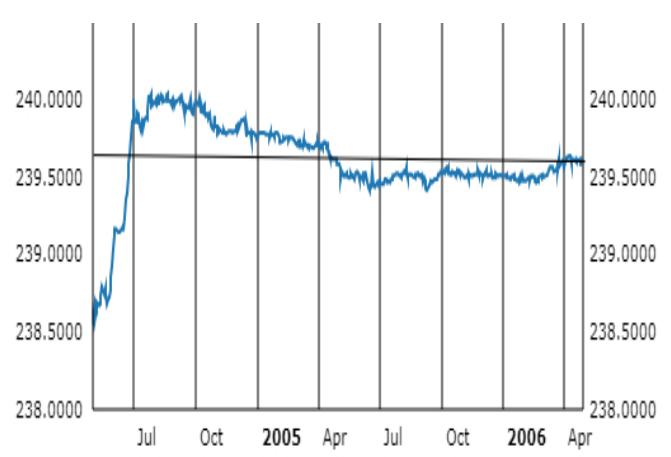

Slovakia

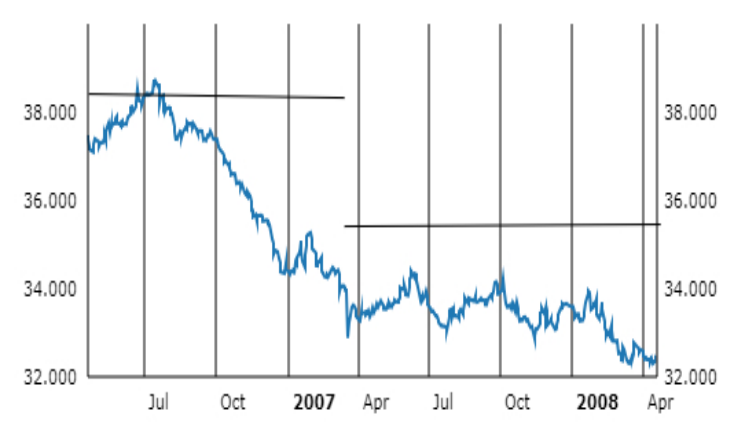

Cyprus

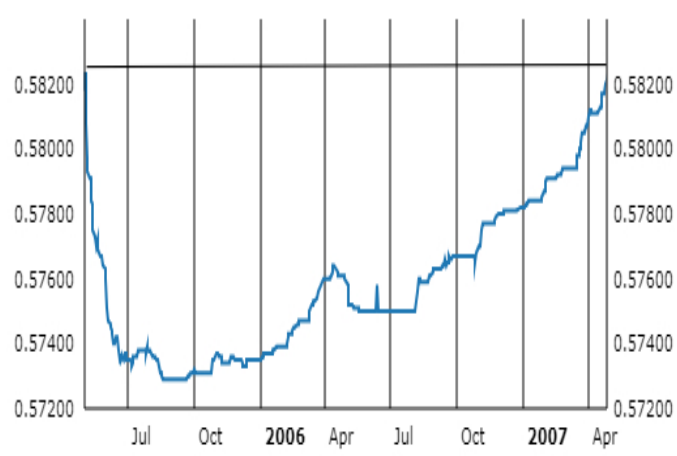

Latvia

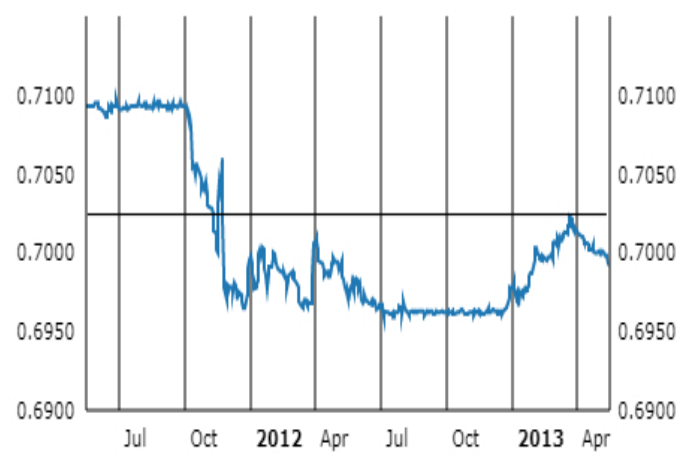

Figure 3. Exchange rate development in relation to the central parity to the euro (National currency/EUR, daily rates)

Sources: European Central Bank http://sdw.ecb.europa.eu/quickview.do?SERIES_KEY=120.EXR.D.SIT.EUR.SP00.A http://sdw.ecb.europa.eu/quickview.do?SERIES_KEY=120.EXR.D.CYP.EUR.SP00.A http://sdw.ecb.europa.eu/quickview.do?SERIES_KEY=120.EXR.D.SKK.EUR.SP00.A http://sdw.ecb.europa.eu/quickview.do?SERIES_KEY=120.EXR.D.LVL.EUR.SP00.A

In case of Slovakia, the chart shows revaluation of the central parity.

Table 1 and Figure 3 show that significant fluctuations of the exchange rate were only in the case the Slovak koruna, but only in the appreciation direction. The response to this was the above-mentioned revaluation of the central parity. Before the introduction of the euro, Slovakia performed a second revaluation (29 May 2008, by 17.6\%). No currency involved in ERM II has experienced the currency crisis which is indicated by the depreciation of the exchange rate.

Other indicators revealing the currency crisis (apart from the depreciation of the exchange rate) are indicators of so-called severe tension. Table 2 contains data on the development of interest rates and foreign exchange reserves, namely:

- maximal differential between three-month interbank interest rates (or Treasury bill rates) and the three-month EURIBOR (in percentage points), for the 24-month period under review,

- change in central bank foreign exchange reserves (in\% of GDP) for the last two calendar years preceding the end of the period under review. 
Severe tension indicators

\begin{tabular}{|l|c|c|c|c|}
\hline \multirow{2}{*}{$\begin{array}{c}\text { Country } \\
\text { (currency) }\end{array}$} & \multicolumn{2}{|c|}{ Interest rate differential } & \multicolumn{2}{c|}{ Change of reserve assets } \\
\cline { 2 - 5 } & positive & negative & first year & second year \\
\hline Slovenia (SIT) & 2.3 & 0.0 & -0.9 & 0.6 \\
\hline Cyprus (CYP) & 2.4 & 0.0 & -4.2 & -5.5 \\
\hline Malta (MTL) & 1.1 & 0.0 & -4.0 & -1.7 \\
\hline Slovakia (SKK) & 1.7 & -0.4 & 4.7 & -5.2 \\
\hline Estonia (EEK) & 5.1 & 0.0 & -3.1 & 0.0 \\
\hline Latvia (LVL) & 0.4 & -0.7 & 4.4 & -3.6 \\
\hline Lithuania (LTL) & 0.5 & 0.0 & -0.4 & 1.3 \\
\hline
\end{tabular}

Sources: European Central Bank, Convergence Report (various years).

For reserve assets of Slovenia: Banka Slovenije and Statistical Office of the Republic of Slovenia (https://apl.bsi.si/pxweb/dialog/Database/ang/serije/03_ekonomski_odnosi/01_placilna_bilanca/01_placilna_bila nca.asp)

(https://pxweb.stat.si/pxweb/Database/Economy/03_national_accounts/05_03019_GDP_annual/05_03019_GD P_annual.asp)

The critical values of these indicators are not arbitrarily determined. However, for any country, the Convergence Report does not evaluate the development of these indicators as a so-called severe tension. Thus, also according to these indicators, no currency has experienced the currency crisis.

\subsection{Specific risks leading to devaluation expectations in ERM II}

As explained in respect of application of the second generation of currency crisis models (Section 5.2), the outbreak of a currency crisis does not require a significant deterioration in the fundamentals. In our opinion, however, investors' uncertainty and their devaluation expectations may also be due to causes other than the development of economic fundamentals. These are specific causes of distrust associated with the participation in ERM II. There are five specific risks. (This approach was explained for the first time in Helísek et al., 2007. We now provide an updated version of this approach.)

Firstly, there is a potential conflict between meeting two criteria, namely the criterion of low inflation and simultaneously the criterion of stable exchange rate, while at the same time there is a free international movement of capital. It is the monetary policy trilemma in an open economy: only two out of three objectives can be achieved. Graphical representation is provided by many authors. It is most clear in Krugman et al. (2015, p. 580). Figure 4 shows three objectives expressed as the vertices of the triangle. If the government wants to keep two of them, it must abandon the third objective described between the two objectives achieved.

If there is a strong inflow of capital, maintaining low inflation is not possible without appreciating the exchange rate. This threatens compliance with the stable exchange rate criterion. These concerns can be weakened by the following arguments:

- the inflation criterion allows the "Maastricht inflation" to be exceeded by $1.5 \mathrm{pp}$,

- the fluctuation band within ERM II is relatively broad, allowing up to $15 \%$ appreciation below the central parity,

- revaluation of the central parity is not in conflict with the fulfilment of the exchange rate criterion. 


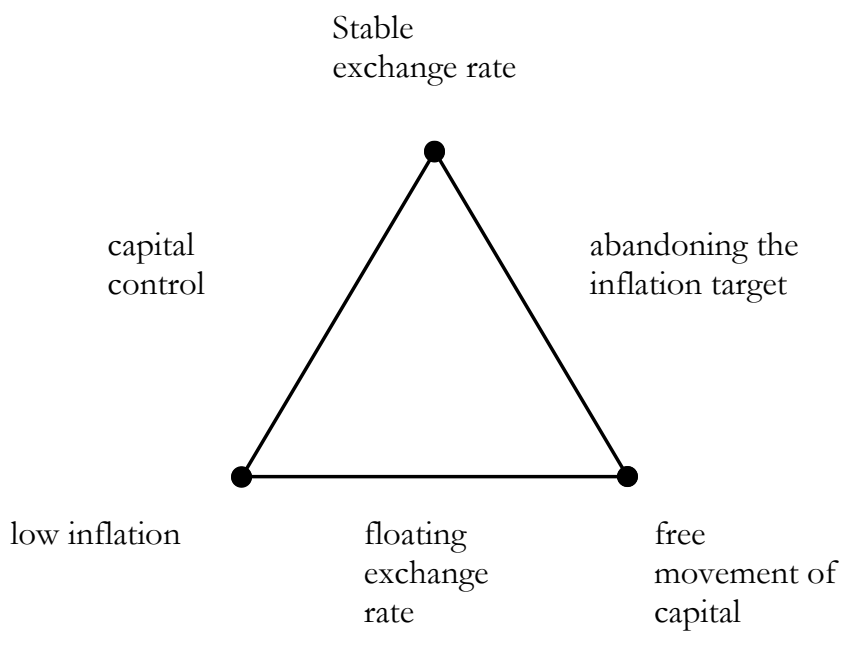

Figure 4. Monetary policy trilemma

Source: own elaboration

The second risk is the setting of the central parity when entering ERM II differently from the current exchange rate. Experience with entering ERM shows that both the undervalued parity (the Greek drachma case) and the overvalued parity (the British pound and the Italian lira case) lead to a subsequent fluctuation in the exchange rate that threatens the compliance with the exchange rate stability condition. Therefore, the ERM II countries have also chosen the central parity to the euro to be either exactly the same as or very close to the current exchange rate. By adhering to this time-proven strategy, the risk of investor distrust of maintaining a fixed exchange rate can be reduced.

Third, there is a risk of an appreciation overshoot of the exchange rate. During the ERM II participation, it is possible to expect strong capital inflows thanks to an increased credibility of the economy fulfilling the Maastricht criteria (low inflation, favourable fiscal indicators). Trust can also be increased by expectations of an accelerated economic growth stemming from the effect of trade growth or from the effect of a decreased risk premium after the adoption of the euro. All of these circumstances can lead to appreciative pressures that will result in overshooting the exchange rate, i.e. in a strong appreciation. This will lead to opposite expectations, to the expectations of exchange rate correction to the central parity, i.e. to its depreciation. However, experience has shown (see section 6.1) that this is a hypothetical risk that has not been empirically confirmed.

The fourth risk is an expected shift in the euro introduction date. It may occur as a result of a (real or only expected) deterioration in the performance of the Maastricht criteria. Investors then begin to predict a cancellation of the central parity and a subsequent depreciation of the exchange rate. This situation can be illustrated by doubts about the fulfilment of fiscal criteria in Slovakia after the 2006 elections. This led to investors' distrust and a slight exceeding of the SKK/EUR exchange rate within the depreciation fluctuation band. However, the central bank interventions compensated for the depreciation pressures.

The fifth risk lies in rejecting an application for joining the euro area. This case occurred in ERM II only once, when Lithuania's euro area application was rejected (decision of the European Commission in 2006, namely due to the failure to meet the inflation criterion). As we can see from the development of LTL/EUR exchange rate (section 6.1), this event also did not lead to devaluation expectations and 
investors' "attack" on the Lithuanian currency. LTL remained in ERM II, meeting the exchange rate stability criterion throughout the following period of time.

\subsection{Deterioration of devaluation expectations}

As explained under the five risks above, we do not consider these risks to be significant. However, they cannot be ruled out. Also, the risk of so-called pure contagion cannot be ruled out (see Section 4.1). If a speculative "attack" on an ERM II currency occurs, we can expect central banks to take measures to maintain the ERM II exchange rate, in particular strong foreign exchange interventions. We explain this by three arguments.

First: The decision to stay in ERM II, which is subject to demanding approval procedures, is a prestigious issue for national central governments (governments, central banks). They want to maintain their credibility, both vis-à-vis the domestic public and the EU authorities.

Second: If the speculative attack was successful and it led to the currency's devaluation from the central parity (or even abandonment of the fixed exchange rate), the currency would no longer fulfil the exchange rate criterion. Upon the next entry into ERM II, another at least two-year ERM II period would begin. This would extend the dangerous period of participation in ERM II, which is (not only for the Czech Republic, but also for other countries) in contradiction with the declared euro area entry strategy, i.e. to stay in ERM II for the shortest possible time.

Third: Should the exchange rate reach the limit of the fluctuation band, the national cedntral bank has basically unlimited access to "very short-term" funding from the ECB. The limitation of this principle is that interventions will not be supported if they are contrary to the primary objective of the ECB, i.e. price stability. However, the relatively small size of the national (e.g. Czech) money market compared to the euro area money market will not be threatened by this inflation risk.

In an extreme case, the European Union rules allow "in the event of a sudden balance-of-payments crisis" also to take "necessary precautionary measures". These measures can be interpreted as temporary restrictions on the movement of capital. We do not take this extraordinary measure into consideration.

\subsection{Modification of the 2nd generation model according to ERM II conditions}

In the previous sections, we explained the specific risks in terms of the causes of devaluation expectations (section 6.2) and the reasons why we believe that these expectations will be weakened by central bank measures (section 6.3). Now we will modify the currency crisis model explained in section 5.2.

1) We replace the fundamental variable on the horizontal axis $(\varepsilon)$ with "specific causes of devaluation expectations" (SC).

2) Weakening of devaluation expectations shifts the $B_{E}$ curve down (from $B_{E}$ to $B_{E S C}$ ).

3) When the currency does not meet the criterion of joining ERM II for at least two years, the authorities of the country lose credibility. In addition, the two-year period must be repeated, which prolongs the remaining period in ERM II. This increases the costs of leaving a fixed exchange rate and moves the $\mathrm{C}$ line up (from $\mathrm{C}$ to $\mathrm{C}_{\mathrm{SC}}$ ). 


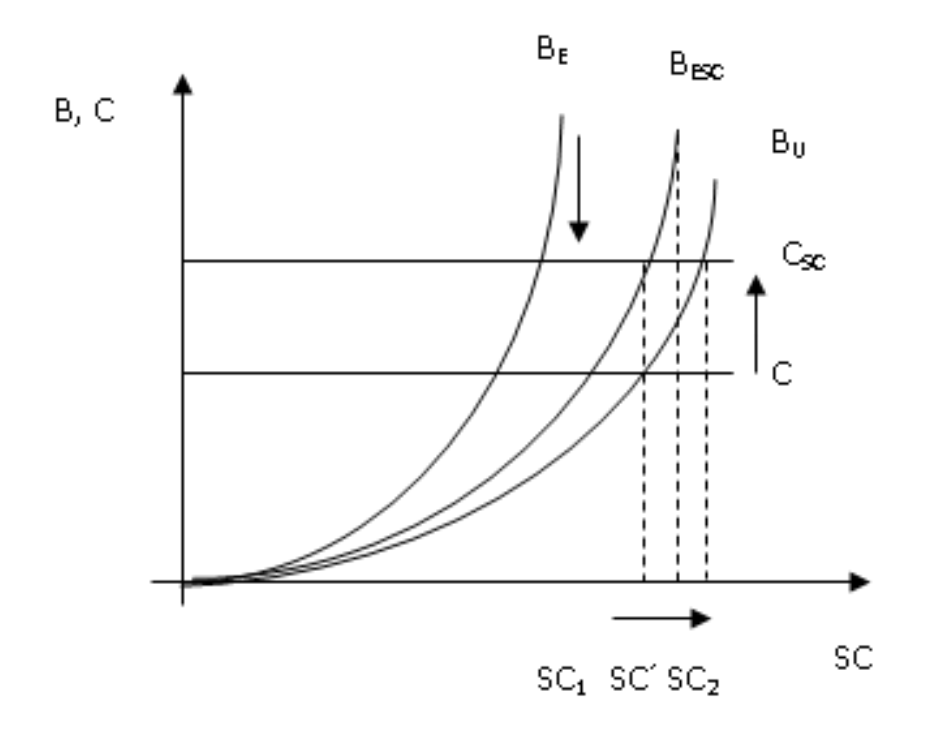

Figure 5. Modification of the $2^{\text {nd }}$ generation model according to ERM II conditions

Source: own elaboration.

Figure 5 shows that under ERM II conditions, the "middle level" of the specific causes of devaluation expectations $\left(\mathrm{SC}^{\prime}\right)$ is shifting to the right. In other words, this means that the reasons for investors' distrust, such as inflow of foreign capital, inappropriate setting of the central parity, etc., must be very strong to cause this distrust.

\section{CONCLUSION}

One of the Maastricht convergence criteria (conditions for joining the euro area) is the currency participation in ERM II for at least two years. The participation in ERM II is conditional on the introduction of a fixed exchange rate regime. The fixed exchange rate is more endangered by a currency crisis than a flexible exchange rate.

We have evaluated the risk of a currency crisis during the participation of the currency in ERM II from two perspectives. First, from an empirical perspective. In the history of ERM II, no currency has been affected by a currency crisis. Second, from a theoretical perspective. The currency crisis in ERM II can be explained by second-generation models that weaken the impact of fundamental causes of investor distrust and underline the impact of devaluation expectations.

Under ERM II, investors' distrust may be due to causes that we have divided into five groups(= specific causes of devaluation expectations in ERM II).We have also found three groups of reasons why central banks will maintain their currency's fixed exchange rate. These causes result in:

- reduction of devaluation expectations,

- and at the same time an increase in the costs associated with abandoning the fixed exchange rate.

Both these circumstances modify the currency crisis model. They increase the "middle level" of the specific causes of devaluation expectations.

Therefore, our conclusion is that concerns over a currency crisis during participation in ERM II are unfounded. 


\section{ACKNOWLEDGEMENT}

The paper has been prepared under the project "New Sources of Systemic Risk in the Financial Markets", supported by the Czech Science Foundation (No. 16-21506S, 2016-2018) and using institutional support for the long-term conceptual development of the research organization University of Finance and Administration.

\section{REFERENCES}

Babecký J., Havránek T., Matějů J., Rusnák M., Šmídková K., \& Vašíček B. (2012).Banking, Debt, and Currency Crises: Early Warning Indicators for Developed Countries. European Central Bank, Working Paper Series No. 1485, October 2012.

Backé, Peter et al. (2004). The acceding countries' strategies towards ERM II and the adoption of the euro - an analytical review, European Central Bank, Occasional Paper, No. 10, February 2004. Retrieved October 20, 2013, from https://www.ecb.europa.eu/pub/pdf/scpops/ecbocp10.pdf

Bordo, M., Eichengreen, B., Kliengebiel, D., \& Martinez-Peria, M. S. (2001). Is the crisis problem growing more severe? Economic Policy, 16 (32), 51-82.

Brasche, U. (2017).Europaische Integration. Wirtschaft, Euro-Krise, Erveiterung und Perspektiven. 4. Auflage. Oldenbourg: De Gruyter.

Bush, O., Farrant, K. \& Wright, M. (2011). Reform of the International Monetary and Financial System. Financial Stability Paper No. 13, December 2011. Bank of England.

Corsetti, G., Pesenti, P., \& Roubini, N. (1999). Paper Tigers? A Model of the Asia Crisis. European Economic Review, 43(7), 1211-1236.

The Czech Republic's Euro Area Accession Strategy. Joint Document of the Czech Government and the Czech National Bank(2003). Retrieved February 24, 20 from http://www.zavedenieura.cz/en/documents/euro-area-accession-strategy.

Czech National Bank (2003). ERM II and the Exchange-rate Convergence Criterion. Information material for the Czech Government.Retrieved20 October 2013 from http://www.zavedenieura.cz/en/documents/euro-areaaccession-strategy

De Grauwe, P. (2016).Economics of Monetary Union. Eleventh Edition. Oxford: Oxford University Press.

Dyson, K. (ed.)(2006). Enlarging the Euro Area. External Empowerment and Domestic Transformation in East Central Europe. Oxford: Oxford University Press.

Eichengreen, B., Rose, A. \& Wyplosz, Ch. (1996). Contagious Currency Crises: First Tests. Scandinavian Journal of Economics, 98 (4), 463-484.

European Central Bank (2016). Convergence Report June 2016. Retrieved May 20, 2017 from https://www.ecb.europa.eu/pub/convergence/html/index.en.html

Flood, R. P., \& Garber, P, M. (1984). Collapsing Exchange-Rate Regimes: Some linear examples. Journal of International Economics, 17(1), 1-13.

Frankel, J., \& Rose, A. (1996). Currency crashes in emerging markets: An empirical treatment. Journal of International Economics, 41(3-4), 351-366.

Ghosh, B. N. (ed.) (2001). Global Financial Crises and Reforms. Cases and caveats. London and New York: Routlege.

Glick, R., \& Hutchison, M. (2011). Currency Crises. Federal Reserve Bank of San Francisco Working Paper Series. WP 2011-22. Retrieved May 10, 2015 from https://www.frbsf.org/economic-research/files/wp11-22bk.pdf

Helísek, M. (2004). Mènové krize (empirie a teorie). Praha: Professional Publishing.

Helísek, M. et al. (2007). Vstup ČR do eurozóny, ERM II a kurzové konvergenční kritérium. Praha: Vysoká škola finanční a správní.

Helisek, M., \& Mentlik, R. (2018). The choice of exchange rate regime for Czech koruna in the context of ERM II participation and the related risks. Journal of International Studies, 11 (1), 124-139. doi:10.14254/2071$8330.2018 / 11-1 / 9$

International Monetary Fund (1998). Financial Crises: Characteristics and Indicators of Vulnerability. World Economic Outlook. May 1998, 74-97. 
Kaminsky, G., Lizondo, S., \& Reinhart, C. M. (1998). Leading Indicators of Currency Crises. International Monetary Fund Staff Papers, 45(1).

Krawczyk, M. K. (2004). A Currency Crisis in Europe? The Europe's common currency and the new accession countries. Hamburg, Hamburgisches Welt-Wirtschafts-Archiv. HWW A Discussion Paper 278. Retrieved May 10, 2015 from http://ageconsearch.tind.io/record/26309/files/dp040278.pdf

Krugman, P. (1979). A Model of Balance of Payments Crises. Journal of Money, Credit and Banking, 11 (3), 311-325.

Krugman, P. (1996). Are Currency crises Self-Fulfilling ?. NBER Macroeconomics Annual, 11, 345-378.

Krugman, P. (1999). Balance Sheet, the Transfer Problem, and Financial Crises. Retrieved May 10, 2015 from http://web.mit.edu/krugman/www/FLOOD.pdf

Krugman, P. (2013). Currency Regimes, Capital Flows, and Crises. 14th Jaques Polak Annual Research Conference, $\begin{array}{llllll}\text { November } & 7-8 & \text { Retrieved } & \text { May } & 10, & 2015\end{array}$ http://www.imf.org/external/np/res/seminars/2013/arc/pdf/Krugman.pdf

Krugman, P., Obstfeld, M., \&Melitz, M. (2015).International Economics. Theory and Policy. Tenth Edition. Edinburgh: Pearson Education Limited.

Lacina, L., Rozmahel P. et al. (2010). Euro: ano/ne? Praha: Alfa.

Marková, J. (2011). Strategie vstupu České republiky do kursového mechanismu ERM II. Český finančni a účetní časopis, $6(2), 18-36$.

Melvin, \&M., Norrbin, S. (2017).International Money and Finance. Ninth Edition. London: Elsevier.

Mentel, G., Brożyna, J., \& Szetela, B. (2017). Evaluation of the effectiveness of investment fund deposits in Poland in a time of crisis. Journal of International Studies, 10(2), 46-60. doi:10.14254/2071-8330.2017/10-2/3

Michalczyk, W.(2011). An Overview to the Exchange Rate Stability as a Criterion of the Accession to the Euro Zone. Folia Oeconomica Stetinensia, 10(1), 120-130.

Obstfeld, M. (1994). The Logic of Currency Crises. Banque de France - Cabiers économiques et monétaires, 43, $189-213$.

Obstfeld, M. (1996). Models of currency crises with self-fulfilling features. European Economic Review, 40(3-5), 10371047.

Otero-Iglesias, Miguel (2014).The Euro, the Dollar and the Global Financial Crisis. Currency Challanges seen from Emerging Markets. New York: Routlege.

Palankai, T. (2015). The Introduction of the Euro and Central Europe, Economics and Sociology, 8(2), 51-69. doi: 10.14254/2071-789X.2015/8-2/5

Radelet, S., \& Sachs, J. (2001). Lesson from the Asian financial crisis. In: Ghosh, B. N. (ed.) Global Financial Crises and Reforms. Cases and caveats. London and New York: Routlege, pp. 295-315.

Sachs, J., Tornell, A., \& Velasco, A. (1996). The Mexican peso crisis: sudden death or death foretold?. Journal of International Economics, 41(3-4), 265-283.

Sychra, Z. (2009). Jednotná evropská mèna. Realizace hospodárské a mènové unie v EU. Brno, Masarykova univerzita.

Zenker, A. (2014). Currency Speculation in Fixed Exchange Rate Regimes. Theory and Empirical Evidence. Wiesbaden: Springer Gabler. 